\title{
Tantangan Media Massa Dalam Menghadapi Era Disrupsi Teknologi Informasi
}

\author{
Reza Ade Putra \\ rezaadepatra_uin@radenfatah.ac.id
}

Program Studi Sistem Informasi, Fakultas Sains dan Teknologi, UIN Raden Fatah Palembang

Diterima: 16 Januari 2019|Direvisi: 05 Maret 2019|Disetujui: 30 Mei 2019

(c) 2019 Program Studi Sistem Informasi Fakultas Sains dan Teknologi,

Universitas Islam Negeri Raden Fatah Palembang, Indonesia

\begin{abstract}
Abstrak: Media massa atau pers, merupakan alat atau sarana penyampaian informasi kepada masyarakat luas melalui media massa seperti media cetak maupun elektronik. Media massa dapat dibagi atas tiga jenis, yaitu media elektronik seperti televisi dan radio, media cetak yaitu koran dan majalah dan terakhir yaitu media online seperti internet, streaming televise dan informasi yang dapat diakses melalui internet. Jumlah pengguna internet yang begitu cepat bertambah ini menjadi semakin meningkat seiring dengan berkembangnya variasi media komunikasi berbasis internet. Pemanfaatannya yang begitu mudah dan dapat diakses dimana saja menjadi pilihan bagi sebagian besar masyarakat. Media cetak pun nyaris tersingkir dengan kehadiran media online. Menyikapi kemungkinan tersebut, maka industri media massa di Indonesia dituntut untuk menyesuaikan dirinya pada era globalisasi berbasis teknologi digital pada saat ini. Salah satu solusi yang diambil adalah digitalisasi koran dalam bentuk e-paper guna menjangkau pembaca yang lebih luas.
\end{abstract}

Kata Kunci: Media Cetak, Media Online, Internet

\begin{abstract}
The mass media or the press, is a tool or means of delivering information to the general public through mass media such as print and electronic media. The mass media can be divided into three types, namely electronic media such as television and radio, print media namely newspapers and magazines and finally, online media such as the internet, streaming television and information that can be accessed via internet. The number of internet users is rapidly increasing as the variety of internet-based communication media develops. It is utilization is so easy and can be accessed anywhere becomes the choice for most people. The newspaper was almost eliminated by the presence of online media. In response to this possibility, the mass media industry in Indonesia is required to adapt itself to the current era of globalization based on cyber media technology. One of the solutions taken was the digitalization of newspapers in the form of e-paper to reach a wider audience.
\end{abstract}

Keywords: Offline Media, Online Media, Internet

\section{PENDAHULUAN}

Media massa atau pers, merupakan alat atau sarana penyampaian informasi kepada masyarakat luas melalui media massa seperti media cetak maupun elektronik. Sesuai dengan definisinya, media massa merupakan suatu istilah yang digunakan untuk mengistilahkan sebuah media yang mampu mencakup dan memberikan informasi langsung kepada masyarakat luas. Media massa dapat dibagi atas tiga jenis yang selama ini sudah tidak asing lagi di mata masyarakat, yaitu media elektronik seperti televisi dan radio, media cetak yaitu koran dan majalah dan terakhir merupakan suatu hal yang sangat populer dan sedang menjadi alat yang dikonsumsi hampir semua masyarakat di era globalisasi yang maju saat ini yaitu media online seperti internet, streaming televise dan informasi yang dapat diakses melalui internet.

Pada Tahun 2018, Asosiasi Penyelenggara Jasa Internet Indonesia (APJII) berkolaborasi dengan Polling Indonesia melakukan survei tentang gambaran terkini dan kemajuan serta 
pertumbuhan internet di Tanah Air. Hasilnya, pengguna internet Indonesia bertambah 10,12 persen pada 2018 dibandingkan tahun sebelumnya. Secara total, pengguna internet mencapai 171,17 juta pengguna dari populasi 264,16 juta jiwa (APJII, 2018).

Jumlah pengguna internet yang begitu cepat bertambah ini menjadi semakin meningkat seiring dengan berkembangnya variasi media komunikasi berbasis internet. Pemanfaatannya yang begitu mudah dan dapat diakses dimana saja menjadi pilihan bagi sebagian besar masyarakat. Media cetak pun nyaris tersingkir dengan kehadiran media online.

Dalam bukunya The Vanishing Newspaper terbitan 2006, Philip Meyer meramalkan bahwa pada Tahun 2044 mendatang hanya akan terdapat satu eksemplar surat kabar. Masa depan surat kabar belakangan ini menjadi pertanyaan besar di tengah gempuran media TV, radio, terutama internet. Sejumlah survei menunjukkan posisi surat kabar mulai tergerus oleh penetrasi media online (Kusuma, 2016). Menyikapi hal itu, media cetak perlu untuk berbenah diri menyesuaikan arus besar yang memaksa setiap media massa melakukan revolusi besarbesaran agar tak ketinggalan zaman dan menjadi bagian sejarah peradaban manusia. Karena jika tidak, ramalan Philip Meyer bisa jadi kenyataan kalau tak ada inovasi baru dari pimpinan media massa untuk menyikapi perkembangan yang ada. Ramalan itu bukan tanpa alasan dan dapat terbukti jika pihak media massa tak mengantisipasi segala perubahan yang terjadi di dunia jurnalistik.

Menyikapi kemungkinan tersebut, maka industri media massa di Indonesia dituntut untuk menyesuaikan dirinya pada era globalisasi berbasis teknologi digital pada saat ini. Fenomena perkembangan era teknologi digital saat ini menuntut media massa di Indonesia untuk melakukan sebuah inovasi terbaru, agar media massa dapat diakses secara cepat dan praktis oleh masyarakat, sebagai pemenuh kebutuhan masyarakat akan informasi yang cepat tepat dan akurat. Maka terciptalah sebuah media massa terbaru yang mampu menjawab tantangan tersebut dan dianggap mampu menjadi solusi bagi media massa agar tetap memiliki eksistensi dalam masyarakat. Salah satu jenis media massa yang saat ini bergerak dan mulai menyesuaikan dengan era globalisasi berbasis teknologi digital dan mulai masuk kedalam konvergensi media saat ini adalah media cetak seperti surat kabar, majalah dan tabloid.

\section{METODOLOGI PENELITIAN}

\subsection{Jenis Penelitian}

Penelitian ini menggunakan pendekatan deskriptif kualitatif yang lebih ditekankan pada upaya untuk mendeskripsikan tantangan dan upaya yang harus dilakukan media cetak dalam menghadapi perkembangan teknologi informasi. Tujuan dari penelitian deskriptif ini adalah untuk membuat deskripsi, gambaran atau lukisan secara sistematis, faktual dan akurat mengenai fakta-fakta, sifat-sifat serta hubungan antara fenomena yang diselidiki.

\subsection{Teknik Pengumpulan Data}

Penelitian ini menggunakan studi pustaka sebagai metode pengumpulan data yang dibutuhkan untuk memperkuat hipotesa yang disertakan dalam penulisan karya ilmiah ini. Studi pustaka yang dilakukan adalah mengumpulkan data yang dibutuhkan dari buku, majalah, dan jurnal-jurnal online yang tersedia di internet.

\section{HASIL DAN PEMBAHASAN}

\subsection{Sejarah Media Cetak di Indonesia}

Media cetak merupakan salah satu jenis media massa yang paling tua jika dibandingkan dengan jenis media massa seperti media elektronik terlebih media online. Dalam sejarah pun tercatat bahwa surat kabar muncul dan ada sejak ditemukan nya sebuah alat mesin cetak oleh Johan Gutenberg di Jerman (Romadhoni, 2018). Sedangkan media cetak di Indonesia lahir dan mulai dikenal sejak ditandai dengan perjalanan yang cukup panjang setelah melalui lima periode yaitu masa penjajahan Belanda, penjajahan Jepang, sebelum 
kemerdekaan dan di masa awal pertama bangsa ini merdeka lalu kemudian masuk lah ke masa orde lama dan orde baru.

Di Indonesia, perkembangan media cetak dimulai dengan surat kabar pertama yang terbit di Batavia pada tahun 1744, yang berjudul "Bataviasche Nouvelles". Lalu tahun 1828 terbitlah "Javasche Courant" di Batavia. Lalu zaman perkembangan media cetak Indonesia pun bergeser ke era di mana media massa cetak berbahasa Melayu sudah mulai diterbitkan, tepatnya dimulai pada tahun 1858. Kala itu koran koran yang terbit adalah Bintang Timur, Bintang Barat, Java Bode, Medan Prijaji, Soerat Khabar Betawi, Hindia Nederland, Bintang Johar, dan Slompret Melajoe.

Kemudian dalam perjalanan nya media cetak di Indonesia tersebut mengalami perkembangan yang begitu pesat dengan mengikuti perkembangan kemajuan teknologi sampai akhirnya kemudian dihadapkan kepada sebuah era baru digital informasi yaitu Era Konvergensi Media. Dalam (Nurliah, 2018), Pavlik menyatakan bahwa konvergensi media adalah bersatunya semua bentuk komunikasi media ke sebuah bentuk elektronik, bentuk digital, yang digerakkan oleh komputer dan berfungsinya teknologi jaringan.

\subsection{Analisis Pengguna Media Cetak}

Pada Tahun 2017, Nielsen Consumer \& Media View melakukan survei di 11 kota dengan mewawancarai 17 ribu responden dan mencapai populasi sebanyak 54 juta orang. Survei hingga triwulan ketiga 2017 menyatakan, kebiasaan membaca orang Indonesia telah mengalami pergeseran. Pada 2017, tingkat pembelian koran secara personal hanya sebesar $20 \%$, menurun dibandingkan 2013 yang mencapai 28\%. Selain itu, media cetak hanya menjadi pilihan kelima masyarakat untuk mendapatkan informasi dengan penetrasi sebesar $7 \%$. Sebaliknya penggunaan internet menjadi pilihan ketiga masyarakat untuk mendapatkan informasi dengan penetrasi sebesar 44\% (Nielsen Consumer and Media View, 2017b).

Tak hanya jumlah pembaca, pengeluaran iklan untuk media cetak pun berkurang. Pada Januari hingga September 2017, jumlah belanja iklan media cetak sebesar 21,8 triliun rupiah, berkurang 13\% dibanding periode yang sama pada 2013 yakni 25 triliun rupiah. Selain itu, produsen media cetak juga berkurang sebesar $23 \%$. Nielsen mencatat ada 268 media cetak pada 2013, namun merosot tajam menjadi hanya 192 media pada 2017. Data ini semakin memperkuat asumsi bahwa media cetak mulai nyata ditinggalkan pembacanya.

Di sisi lain, alasan utama para pembaca masih memilih koran adalah karena nilai beritanya yang dapat dipercaya, sedangkan untuk tabloid atau majalah lebih kepada kisah nyata yang diulas. Jika dilihat dari profil pembaca, media cetak di Indonesia cenderung dikonsumsi oleh konsumen dari rentang usia 20-49 tahun (74\%), memilki pekerjaan sebagai karyawan $(32 \%)$ dan mayoritas pembacanya berasal dari kelas atas (54\%). Ini menunjukkan bahwa pembaca media cetak masih produktif dan dari kalangan yang mapan (Nielsen Consumer and Media View, 2017a).

Dengan semakin berkembangnya teknologi, pembaca media cetak juga menggunakan internet dalam kehidupan sehari-hari. Sebanyak $65 \%$ pembaca media cetak mengakses internet melalui smartphone dan menghabiskan waktu dengan internet hampir 3 jam setiap harinya. Kepembacaan melalui internet atau digital juga cukup tinggi. Menurut data Nielsen Consumer and Media View, sampai dengan kuartal ketiga 2017, jumlah pembaca versi digital mencapai 6 juta orang dengan penetrasi sebesar 11 persen. Ini membuktikan bahwa minat membaca tidak turun, tapi hanya berganti platform saja.

\subsection{Strategi Adaptasi Media Cetak}

Masuknya era konvergensi media di Indonesia ditandai dengan banyaknya media yang bergabung atau jenis media massa seperti media elektronik, media cetak bergabung menjadi satu media yang dapat diakses sekaligus dengan menggunakan akses internet. Kemampuan media online mendistribusikan berita dengan gratis, lebih cepat, interaktif dan saat itu juga (event on the making) dianggap media massa mainstream sebagai kondisi yang tepat untuk memperluas jaringan pembaca dan yang cukup penting menumbuhkan loyalitas. 
Platform media, terutama media cetak, harus menyesuaikan dan mengadopsi teknologi digital untuk mempertahankan eksistensinya dan terus berkembang di era teknologi digital yang semakin tak terbendung. Media cetak akan mati jika tetap bertahan dengan konsep konvensional dan tidak mau menyesuaikan dengan perkembangan teknologi digital.

Pada masa dahulu, teknologi hanya dianggap sebagai objek oleh media cetak. Tetapi, saat ini, teknologi digital telah menjadi subjek bagi media cetak. Artinya, teknologi digital telah dan mulai menjadi subjek utama bagi media cetak dalam memperkenalkan konten atau berita kepada pembacanya. Pembaca kini mulai mengandalkan kepraktisan dalam menikmati berita atau konten dengan menggunakan smartphone dan tablet (gadget) seiring perkembangan teknologi yang semakin memudahkan kehidupan manusia. Perusahaan media cetak pun dituntut tidak hanya menyandarkan diri pada operasional dan pendapatan dari sisi cetak semata, tetapi juga sisi pemasaran multi-channel, termasuk pemasaran digital. Oleh karena itu, inovasi teknologi sangat dibutuhkan untuk mempertahankan keberadaan media cetak. Salah satu solusi yang diambil adalah digitalisasi koran dalam bentuk e-paper guna menjangkau pembaca yang lebih luas.

Adaptasi terhadap perilaku konsumen menjadi pilihan yang tidak bisa ditawar agar informasi yang disajikan dapat dinikmati oleh kebanyakan pengguna. Industri media cetak harus dapat menyesuaikan diri dengan perubahan perilaku konsumen sambil tetap melakukan inovasi bisnis. Pendapat Robert G. Pickard, professor bidang ekonomi media dan manajemen sekaligus peneliti senior di Reuters Institute, University of Oxford yang menyatakan bahwa industri media cetak tidaklah mati karena gempuran digital ternyata relevan .

Tantangan terbesar yang dihadapi oleh pebisnis media cetak yaitu bagaimana menjadikan teknologi digital menjadi cara baru dalam mengoperasikan bisnis serta menjadi peluang untuk berkembang dan tumbuh. Karena itu butuh visi yang jelas untuk menjadikan teknologi digital mampu membuat media cetak hidup lebih berwarna. Pada saat yang sama, butuh tebaran optimisme bahwa adanya teknologi digital adalah keniscayaan dan menjadi tantangan yang harus dihadapi dengan cerdik dan kreatif (Pickard G. Picard, 2017).

Kita masuk ke dalam salah satu contoh hasil dari era media online yang menawarkan akses informasi media cetak, media elektronik dan media online di konvergensikan menjadi satu akses. Detik.com merupakan situs warta era digital yang dibawahi di dalam Trans Corporation. Dalam situs tersebut terdapat berbagai macam akses informasi diantarannya Detik News yang memberikan informasi layaknya sebuah media cetak namun dikemas sedikit lebih update dan diinformasikan kepada masyarakat lebih cepat dibandingkan media cetak dalam bentuk koran, surat kabar dan lain-lain.

Jika dibandingkan dengan media cetak, media online menyajikan informasi yang lebih cepat dikabarkan dan disajikan serta lebih update sehingga masyarakat tidak perlu untuk menunggu lama mendapatkan informasi yang ingin dilihat atau yang sedang menjadi perbincangan hangat. Ilustrasinya begini, jika ada sebuah pertandingan sepakbola yang dilangsungkan dini hari, maka selesai pertandingan itu juga media online mampu memunculkan berita agar dapat diakses masyarakat. Berbeda dengan media cetak yang masih membutuhkan waktu berjam-jam untuk menyampaikan berita terbaru. Sehingga jelas rentangan perbedaan waktu yang mencolok antara media online dengan media cetak, membuat jeda yang cukup lama tersebut akan menggiring masyarakat untuk melirik media informasi internet yang menyajikan beragam berita secara cepat, yang diiringi fenomena pembaca koran mau tak mau harus berpindah memanfaatkan Internet untuk mengupdate informasi.

Studi kasus media massa yang mengambil langkah strategis dalam hal pemasaran yaitu Harian Kompas. Untuk menjaga stabilitas dan eksistensinya, harian Kompas sebagai media konvensional tersohor melakukan ekspansi ke media digital dengan meluncurkan kompas.com, Aplikasi Kompas.id tersedia di platform Android dan iOS, Kompas Editor's Choice untuk pembaca yang menggunakan iPad dan sebagainya. Selain itu kompas mengeluarkan koran elektronik epaper.kompas.id. Kompas sebagai koran terbesar oplahnya, sekitar 500 ribu eksemplar per hari dan menjadi koran ternama nomor 103 dunia.

Volume 5, Nomor 1, Juni 2019 
Antisipasi yang dilakukan manajemen kompas dapat mempertahankan konsumen koran analog atau koran cetak dengan memelihara hubungan dengan konsumennya di media digital Kompas. Mereka tetap membaca Kompas di media digital dan tentunya juga membeli koran. Pangsa pasar dapat dijaga agar tidak lupa dengan koran Kompas.

\section{KESIMPULAN}

Akhirnya memang saat ini media cetak sedang ditantang eksistensi nya di era konvergensi media saat ini, selanjutnya bagaimana media cetak tersebut dapat tetap mempertahankan apa yang menjadi nilai lebih dari media cetak tersebut yang tidak bisa didapatkan masyarakat pada teknologi canggih sekalipun di era yang teknologinya sudah canggih seperti ini. Di masa depan tantangan media cetak akan semakin besar dengan terus bertambahnya inovasi-inovasi terbaru yang akan menjadi pilihan dalam membantu masyarakat pada bidang media massa dan informasi. Namun jika media cetak dapat mempertahankan keutamaan informasi dan profesionalitas maka media cetak akan senantiasa hadir dan eksis di tengah masyarakat.

\section{DAFTAR RUJUKAN}

APJII. (2018). Penetrasi \& Profil Perilaku Pengguna Internet Indonesia. Apjii. Retrieved from www.apjii.or.id

Kusuma, S. (2016). POSISI MEDIA CETAK DI TENGAH PERKEMBANGAN MEDIA

ONLINE DI INDONESIA Satria Kusuma. Interact, 5(1), 56-71.

Nielsen Consumer and Media View. (2017a). MEDIA CETAK MAMPU MEMPERTAHANKAN POSISINYA - Nielsen. Retrieved July 31, 2019, from https://www.nielsen.com/id/en/press-releases/2017/MEDIA-CETAK-MAMPU-

MEMPERTAHANKAN-POSISINYA/

Nielsen Consumer and Media View. (2017b). TREN BARU DI KALANGAN PENGGUNA

INTERNET DI INDONESIA - Nielsen. Retrieved July 31, 2019, from https://www.nielsen.com/id/en/press-releases/2017/tren-baru-di-kalangan-penggunainternet-di-indonesia/

Nurliah, N. (2018). Konvergensi dan Kompetisi Media Massa dalam Memenangkan Pasar di Era Media Digital di Makassar. Jurnal Dakwah Tabligh, 19(1), 106-118. https://doi.org/10.24252/jdt.v19i1.5951

Pickard G. Picard, V. P. (2017). Essential Principles for Contemporary Media and Communications Policymaking. Reuters Institute for the Study of Journalism: University of Oxford., (April).

Romadhoni, B. A. (2018). Meredupnya Media Cetak, Dampak Kemajuan. An-Nida, 10(1), 1320. 
